\title{
Illustrations and Table
}

\section{FIGURES}

I. An instant noodle block / I3

2. Calligraphy for health, food, gratefulness / 40

3. The Ajinomoto garden / 40

4. A Shōwa kitchen from the I960s / 4 I

5. Schoolchildren at the Instant Ramen Museum / 48

6. A statue of Momofuku Ando / 49

7. A reconstruction of Ando's shack / 50

8. Cup Noodle revealed / 52

9. Hiyoko-chan, the Nissin chick / 53

ıo. Personalizing Cup Noodle / 54

I I. Mana Fujikura chooses Cup Noodle toppings / 55

I2. Making Chicken Ramen / 56

I3. The Instant Noodles Tunnel / 58

I4. Prisoners share an instant noodle "spread" / 77

I 5. A hub vending box at the Lae Market in Papua New Guinea / 9 I

I6. Instant noodles at a roadside stand / 93

I7. Nestlé PNG product line display / 95 
viii | Illustrations and Table

I8. Meals, Ready-to-Eat / I I 4

I9. MRE package deconstructed / I I 7

TABLE

I. Lipid Comparison / 27 